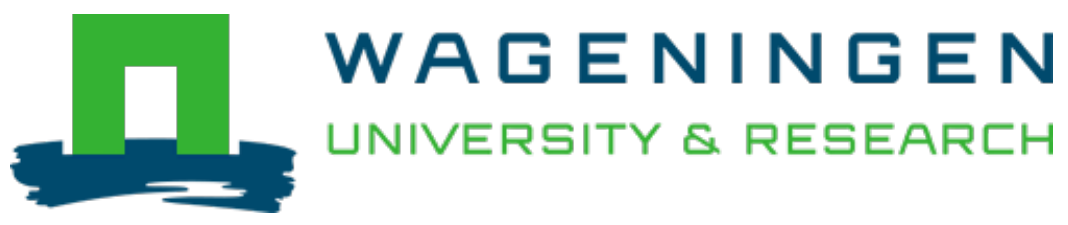

\title{
Biological Control Agents for Control of Pests in Greenhouses
}

\author{
Integrated Pest and Disease Management in Greenhouse Crops \\ Lenteren, Joop C.; Alomar, Oscar; Ravensberg, Willem J.; Urbaneja, Alberto \\ https://doi.org/10.1007/978-3-030-22304-5 14
}

This article is made publicly available in the institutional repository of Wageningen University and Research, under the terms of article $25 \mathrm{fa}$ of the Dutch Copyright Act, also known as the Amendment Taverne. This has been done with explicit consent by the author.

Article $25 \mathrm{fa}$ states that the author of a short scientific work funded either wholly or partially by Dutch public funds is entitled to make that work publicly available for no consideration following a reasonable period of time after the work was first published, provided that clear reference is made to the source of the first publication of the work.

This publication is distributed under The Association of Universities in the Netherlands (VSNU) 'Article $25 \mathrm{fa}$ implementation' project. In this project research outputs of researchers employed by Dutch Universities that comply with the legal requirements of Article $25 \mathrm{fa}$ of the Dutch Copyright Act are distributed online and free of cost or other barriers in institutional repositories. Research outputs are distributed six months after their first online publication in the original published version and with proper attribution to the source of the original publication.

You are permitted to download and use the publication for personal purposes. All rights remain with the author(s) and / or copyright owner(s) of this work. Any use of the publication or parts of it other than authorised under article $25 \mathrm{fa}$ of the Dutch Copyright act is prohibited. Wageningen University \& Research and the author(s) of this publication shall not be held responsible or liable for any damages resulting from your (re)use of this publication.

For questions regarding the public availability of this article please contact openscience.library@wur.nl 


\title{
Chapter 14 \\ Biological Control Agents for Control of Pests in Greenhouses
}

\author{
Joop C. van Lenteren, Oscar Alomar, Willem J. Ravensberg, \\ and Alberto Urbaneja
}

\begin{abstract}
First we describe the different types of biocontrol used in greenhouses and present examples of each type. Next we summarize the history of greenhouse biocontrol, which started in 1926, showed a problematic period when synthetic chemical pesticides became available after 1945, and flourished again since the 1970s. After 1970, the number of natural enemies becoming available for commercial augmentative biocontrol in greenhouses grew very fast, as well as the industry producting these control agents. Biocontrol of the most important clusters of greenhouse pests is summarized, as well as the taxonomic groups of natural enemies that play a main role in greenhouses. More than $90 \%$ of natural enemy species used in greenhouses belong to the Arthropoda and less than $10 \%$, many belonging to the Nematoda, are non-arthropods. This is followed by sections on finding and evaluation of potential biocontrol agents, and on mass production, storage, release and quality control of natural enemies. Since the 1970s, production of biocontrol agents has moved from a cottage industry to professional research and production facilities. Many efficient agents have been identified, quality control protocols, massproduction, shipment and release methods matured, and adequate guidance for farmers has been developed. Most natural enemy species (75\%) are produced in low or medium numbers per week (hundreds to a hundred thousand), and are applied in
\end{abstract}

J. C. van Lenteren $(\bowtie)$

Laboratory of Entomology, Wageningen University, Wageningen, The Netherlands

e-mail: Joop.vanLenteren@wur.nl

O. Alomar

Institut de Recerca i Tecnologies Agroalimentàries (IRTA), Centre de Cabrils, Cabrils, Spain e-mail: oscar.alomar@irta.es

W. J. Ravensberg

Koppert Biological Systems, Berkel en Rodenrijs, The Netherlands

e-mail: wravensberg@ koppert.nl

A. Urbaneja

InstitutoValenciano de Investigaciones Agrarias (IVIA), Centro de Protección Vegetal y

Biotecnología, Moncada, Spain

e-mail: aurbaneja@ivia.es 
situations where only low numbers are needed, such as private gardens, hospitals, banks, and shopping malls. The other $25 \%$ of the species are produced in numbers of 100,000 to up to millions per week and regularly released in many of the greenhouse crops. Microbial pesticides are predominantly used as corrective treatments in greenhouse crops where natural enemies are providing insufficient control. Europe is still the largest commercial market for arthropod greenhouse biocontrol agents, and North America is the largest market for microbial control agents. We then continue with a discussion on the pros and cons of use of polyphagous predators, and the use of semiochemicals. Finally, we summarize factors that indicate a positive future for greenhouse biocontrol, as well as developments frustrating its implementation.

Keywords Natural biocontrol · Conservation biocontrol - Classical biocontrol · Augmentative biocontrol · Inundative biocontrol - Seasonal inoculative control · Polyphagous predators $\cdot$ Semiochemicals $\cdot$ Mass production

\subsection{A Short History of Natural Enemy Use for Pest Control in Greenhouses}

Different types of biological control - here defined as the use of a population of one organism to reduce the population of another organism - are used in greenhouses. Natural biological control (NatBC), whereby natural enemies which occur in the environment reduce pest populations, is observed in countries where greenhouse structures are often partly open like in the Mediterranean Basin, tropics and semitropics. Surprisingly, natural biological control is even observed in temperate climates. Examples are (1) natural control of exotic leafminer species by native parasitoids (e.g. Dacnusa sibirica Telenga (Hymenoptera: Braconidae), Diglyphus isaea (Walker) (Hymenoptera: Eulophidae), and Opius pallipes Wesmael (Hymenoptera: Braconidae)), pest mites that are controlled by naturally occurring gall midges (Feltiella acarisuga (Vallot) (Diptera: Cecidomyiidae)), and lepidopterans controlled by naturally occurring parasitoids (e.g. Euplectrus sp.) (van Lenteren 2010; van der Ent et al. 2017). Other spontaneously occurring parasitic wasps, such as Cotesia spp., Eulophus spp., Euplectrus spp., and Necremnus artynes (Walker) (Hymenoptera: Eulophidae) can make an important contribution to the biocontrol of native and exotic lepidopteran pests in the Mediterranean region (van der Ent et al. 2017). NatBC can be improved by growing plants near greenhouses that provide nectar, pollen or refuge for natural enemies, or by placing such plants inside the greenhouse. In that case we speak about conservation biological control, which consists of human actions that protect and stimulate the performance of naturally occurring natural enemies. Conservation biological control (ConBC) is 
currently receiving a lot of attention and is expected to be used increasingly, also for control of pests in greenhouses (see other chapters in this book). Further, we may use classical biological control (ClasBC), where natural enemies are collected in an exploration area (usually the area of origin of the pest) and then inoculated, i.e. released in low numbers in areas where the pest is invasive. However, in classical biological control the aim is permanent pest population reduction and this is not easy to obtain in greenhouse crops that are grown for short periods only. Still ClasBC may play a role in reducing pests outside the greenhouse area on wild plants, thereby contributing to lower pest pressure inside the greenhouse. An example is the generalist parasitoid Lysiphlebus testaceipes (Cresson) (Hymenoptera: Braconidae), which was introduced from Cuba in 1976 into Spanish citrus orchards for control of Toxoptera aurantii Boyer de Fonscolombe (Hemiptera: Aphididae) (Jacas et al. 2006). After introduction, this parasitoid established throughout the Mediterranean agricultural area where its parasitic action on natural populations of Aphis gossypii Glover (Hemiptera: Aphididae) has resulted in a lower impact of this pest aphid on horticultural and ornamental crops. Some greenhouse crops - e.g. roses and gerberas - are grown during several years and situations can be created that resemble classical biological control: natural enemies of exotic origin are released in low numbers (inoculated) at the start of a production cycle and exert control during many pest populations. In this case we speak about seasonal inoculative releases, and it differs from inundative releases, whereby large numbers of natural enemies are released for immediate pest control in crops with a short production cycle. Often seasonal inoculative and inundative are addressed under the umbrella of augmentative biological control (ABC), the form of biocontrol where natural enemies are mass reared for periodic releases (Van Lenteren et al. 2018a). ABC has always been the most used type of biocontrol in greenhouses, but as said above the use of ConBC is growing.

The documented history of biocontrol in greenhouses goes back to 1926 . Biocontrol might have been used long before, for example by having cats for control of mice in protected structures where food was produced or stored. In 1926, a tomato grower observed black pupae among the normally white nymphs of the greenhouse whitefly, Trialeurodes vaporariorum Westwood (Hemiptera: Aleyrodidae), and later, adult parasitoids emerged that were identified as Encarsia formosa Gahan (Hymenoptera: Aphelinidae) (Speyer 1927). A research station in England started to mass rear the parasitoid and a few years later, it was annually supplying 1.5 million parasitoids to about 800 nurseries in Britain. During the 1930s E. formosa was shipped to other countries in Europe, Australia, Canada and New Zealand. Mass production was discontinued for a short period after 1945 because synthetic pesticides became available. Due to quick development of resistance to pesticides in greenhouses, particularly in spider mites, interest in biocontrol revived. First a predatory mite (Phytoseiulus persimilis (Athias-Henriot) (Acari: Phytoseiidae)) of the spider mite (Tetranychus urticae Koch (Acari: Tetranychidae)) was found and put into practice with great success in the 1960s (Hussey and Bravenboer 1971). Later, the use of the parasitoid E. formosa became popular again in the 1970s. Also biocontrol of other pests, such as aphids, thrips, and exotic inva- 
sive and native leafminers was developed, and successful mass-rearing and distribution systems emerged. This was for a large part the result of very good collaboration between researchers and the natural enemy industry within the two working groups "Integrated Control in Protected Crops" in Mediterranean and temperate climates of the European section of the International Organization of Biological Control (www. IOBC-WPRS.org). These working groups published (and are still publishing) bulletins with a wealth of information on greenhouse IPM topics. For a detailed review of development of IPM in greenhouses up to 1985, we refer to van Lenteren and Woets (1988); for the period up to 2000 to van Lenteren (2000), who also provides an IPM programme for tomato, the largest greenhouse vegetable crop worldwide. IPM programmes for other vegetables and ornamentals, and biocontrol agents used until the end of the 1990s can also be found in Cavalloro and Pellerents 1989; Albajes et al. (1999). Arnó et al. (2018) highlight major landmarks in the development of biocontrol programmes for tomato greenhouses in the Mediterranean.

During the period 1970-2000 the number of natural enemies becoming available for commercial augmentative biocontrol grew very fast (Fig. 14.1). After 2000 and until today, a much lower number of new natural enemies came to the market. The decrease was for one part due to various positive developments as (1) the availability of complete sets of biocontrol agents managing the key pests and diseases in

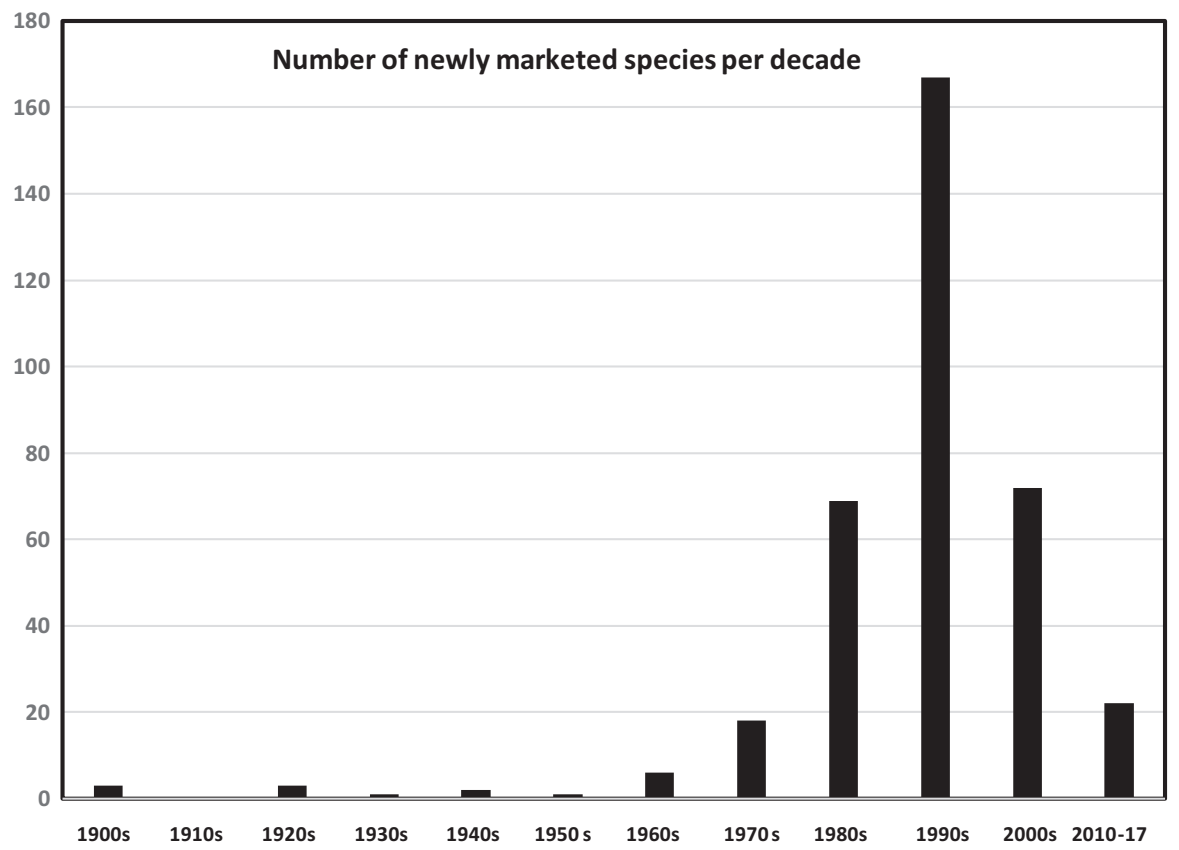

Fig. 14.1 Number of newly marketed invertebrate natural enemy species per decade for augmentative biocontrol (based on tables and supplementary material in van Lenteren et al. 2018a and with recent updates) 
greenhouses, (2) the increased use of generalist predators and (3) the growing popularity of conservation biocontrol approaches. However, the reduction was for another part due to stronger regulation of import of exotic natural enemies, increased demands concerning registration of biocontrol agents, and the Access and Benefit Sharing paragraph in the Convention of Biological Diversity resulting in the Nagoya Protocol which recently came into force (Secretariat of the Convention on Biological Diversity 2011). All these new measures have negatively affected market penetration of new biocontrol agents and, whether they are of indigenous or exotic origin, now usually undergo an environmental risk assessment (Cock et al. 2010; van Lenteren et al. 2006). Due to the current evaluation and registration requirements, a trend has developed to first look for indigenous agents, even when a new exotic pest establishes. Until a few years ago, prospecting for new, exotic natural enemies after accidental introductions of exotic pests was common practice, but particularly the Access and Benefit Sharing process has resulted in an almost complete stop of foreign natural enemy exploration programmes (Cock et al. 2010). We can illustrate this trend by the number of natural enemies that have been used in augmentative biocontrol for the first time in Europe (Fig. 14.2). Until 1970, the only two species commercially used in European greenhouses - P. persimilis and E. formosa - were exotics. During the period from 1960 to 1999, more new exotic species (77) were used than indigenous species (58). As of 2000, this trend changed and for the first time more indigenous species (18) were commercialized than exotic species (6).

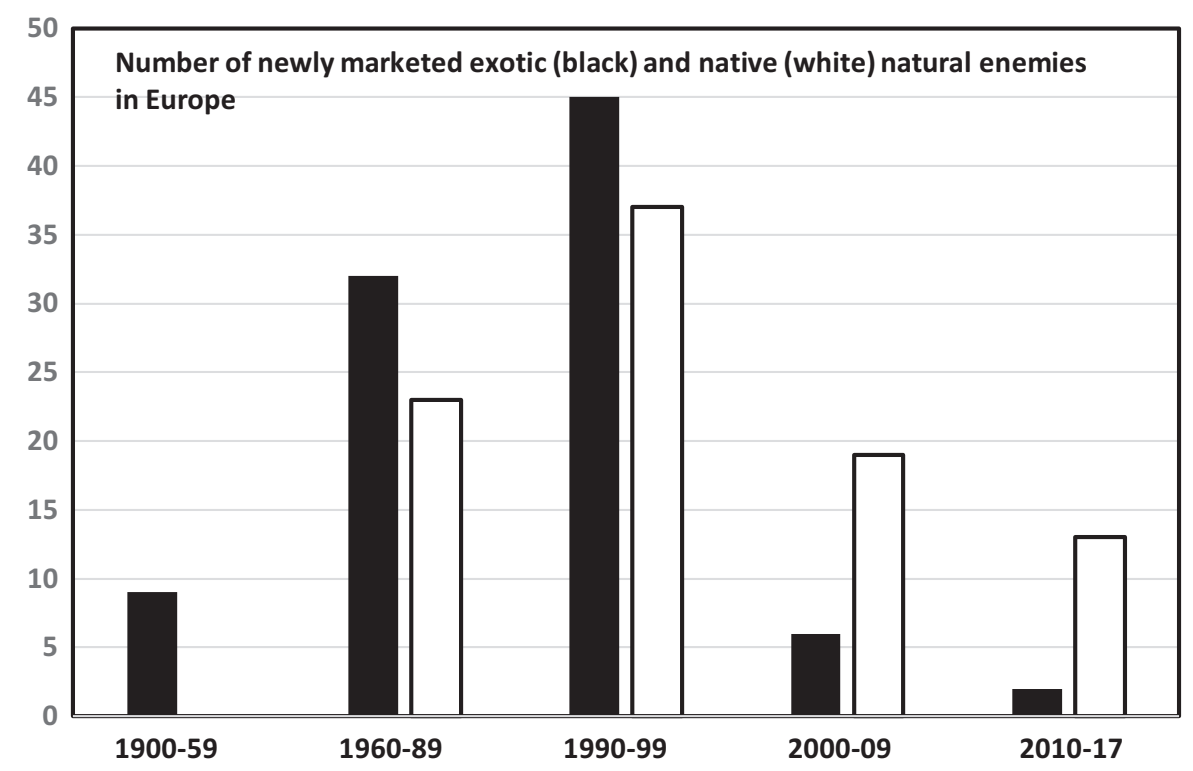

Fig. 14.2 Numbers of new exotic (black) and indigenous (white) invertebrate natural enemies introduced for augmentative biocontrol to the European market. (Based on tables and supplementary material in van Lenteren et al. 2018a and with recent updates) 
The majority ( $>90 \%$ ) of natural enemy species used in $\mathrm{ABC}$ belongs to the Arthropoda and less than $10 \%$ of the species, many belonging to the Nematoda, are non-arthropods. Within the arthropods, four taxonomic groups provided most natural enemies expressed in number of species: Hymenoptera $(>50 \%)$, Acari (about 15\%), Coleoptera (about 12\%) and Hemiptera (about 8\%) (van Lenteren 2012; van Lenteren et al. 2018a). The large number of hymenopteran species used in ABC can be explained by the fact that they have, compared to predators, a much more restricted host range, which is considered important in preventing undesirable side effects (e.g. Bigler et al. 2006). Acarid predators are popular because they can cheaply be mass reared, can be released by mechanical means, may control several pest species, do not spread actively over large distances, which reduces the risk of undesirable effects. An example of a recent acarid species becoming very popular in use is Amblyseius swirskii Athias-Henriot (Acari: Phytoseiidae) (e.g. Calvo et al. 2012a). Interestingly, polyphagous heteropteran predators have become increasingly popular in $\mathrm{ABC}$ during the past two decades (see Table 14.1 in van Lenteren 2012, and Table 14.2 in van Lenteren et al. 2018a). This was a somewhat unexpected development as several of the currently used heteropteran species have a very wide prey range and some of them are (facultatively) phytophagous (Wheeler 2001; Pérez-Hedo et al. 2015). See Sect. 14.5 of this chapter for a more detailed discussion of the use of polyphagous predators in greenhouse IPM.

Most natural enemy species (75\%) are produced in low or medium numbers per week (hundreds to a hundred thousand) (van Lenteren 2012; van Lenteren et al. 2018a). They are applied in situations where only low numbers are needed (private gardens, hospitals, banks, shopping malls, etc.), or when occasionally needed in large cropping systems for control of minor pests. An example of a taxonomic group mainly used in niche markets is the Coleoptera; more than $90 \%$ of the species are

Table 14.1 Major biocontrol agent producers providing beneficial organisms and information on greenhouse pest management. For lists with more producers, see e.g. http://www.ibma-global.org/ en/all-ibma-members, and http://anbp.org/index.php/members-products

\begin{tabular}{l|l|l}
\hline Name of company & Area where active & URL \\
\hline Agrobio & Global & www.agrobio.es \\
\hline Applied Bionomics & NAFTA & www.appliedbio-nomics.com \\
\hline BASF & Global (EPNs) & www.basf.com \\
\hline Beneficial Insectary & NAFTA & www.insectary.com \\
\hline Biobee & Global & www.biobee.com \\
\hline Biobest & Global & www.biobest.be \\
\hline Bioline Agrosciences & Europe, NAFTA & www.biolineagrosciences.com \\
\hline Biological Services & Australia & www.biologicalservices.com.au \\
\hline Bioplanet & S. Europe & www.bioplanet.eu/it/ \\
\hline Bugs for bugs & Australia & www.bugsforbugs.com.au \\
\hline Dudutech & E. Africa & www.dudutech.com \\
\hline Enema & Global (EPNs) & www.e-nema.de \\
\hline Koppert Biological Systems & Global & www.koppert.com \\
\hline
\end{tabular}




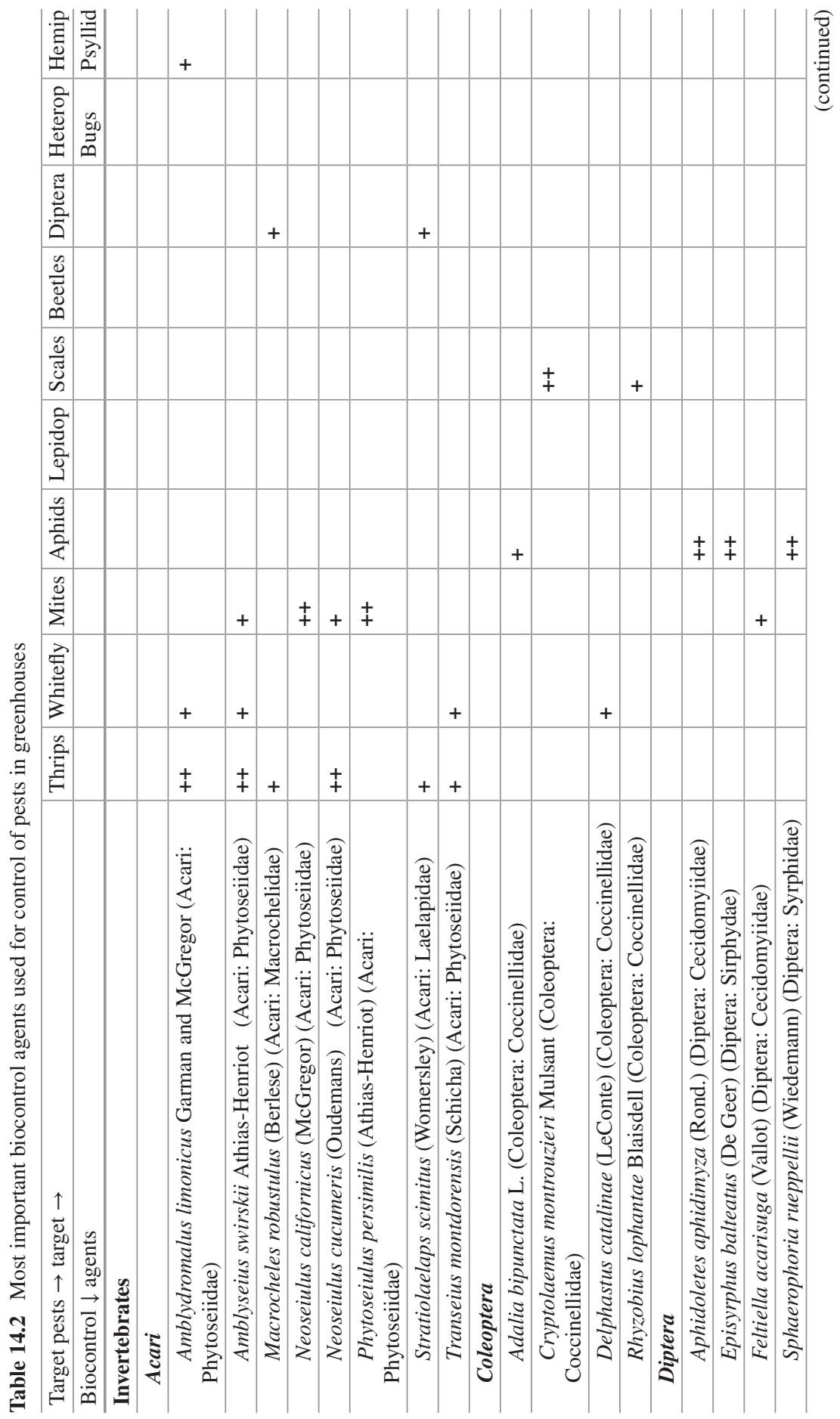




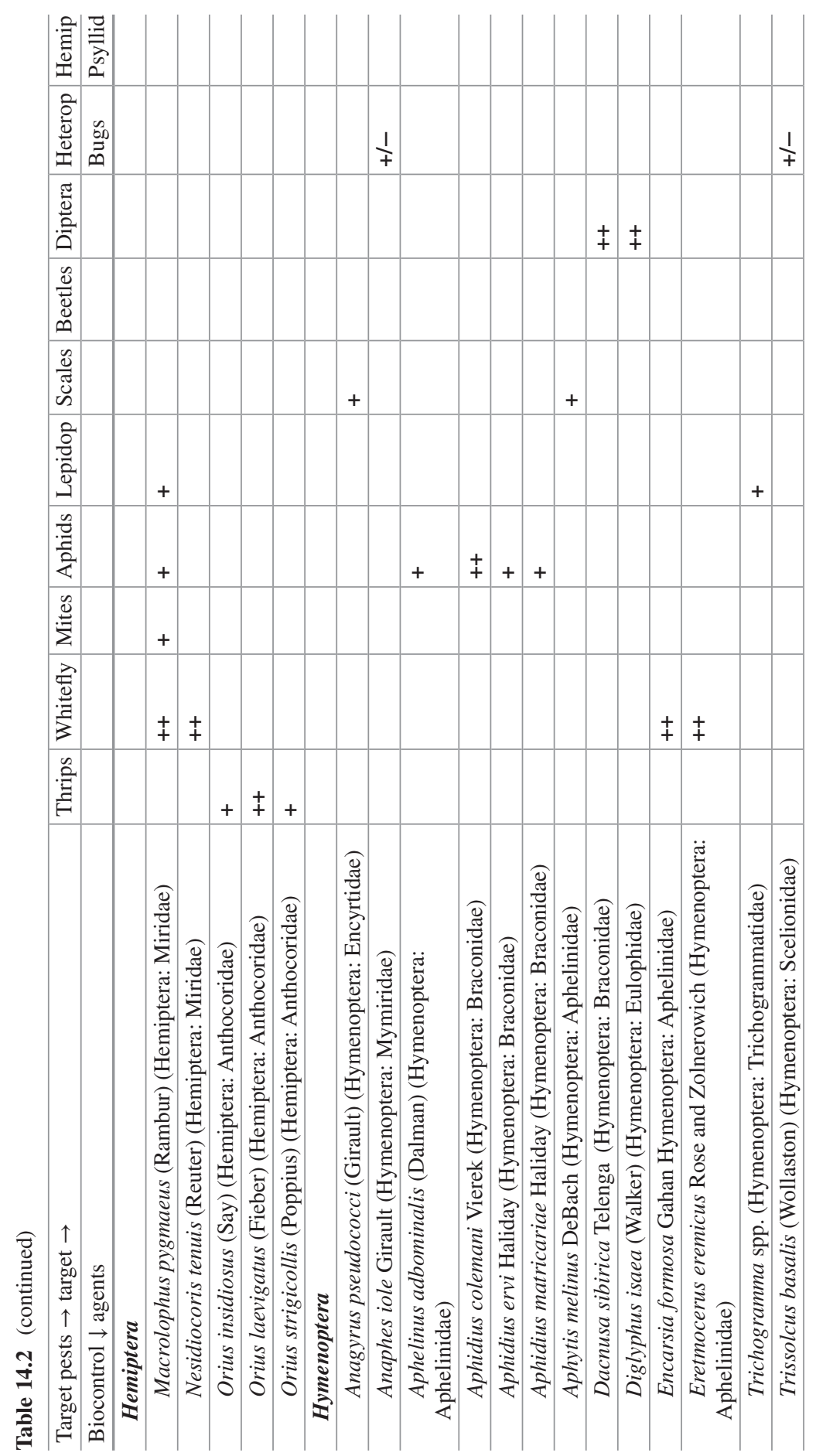




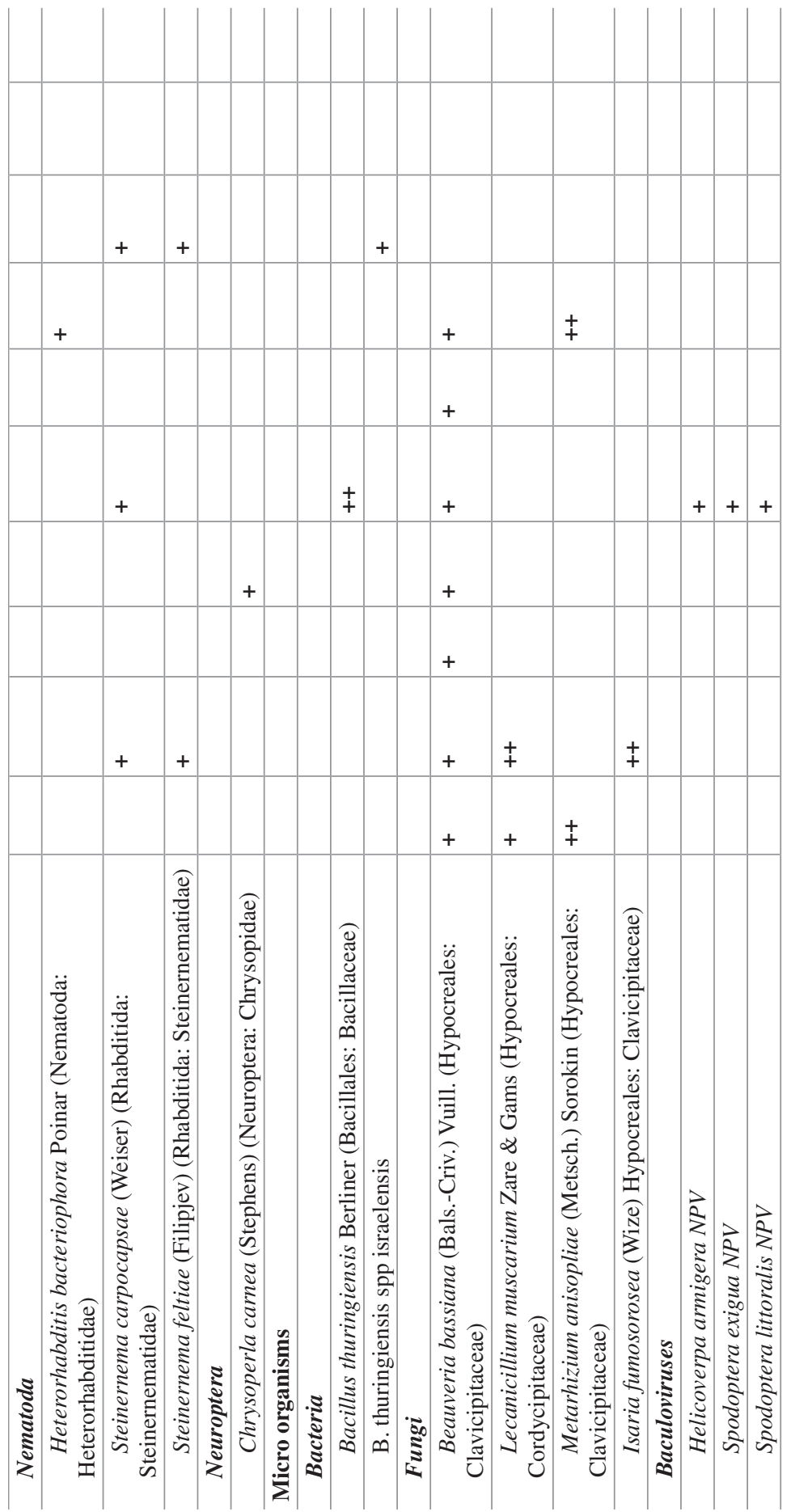


produced in small numbers. Twenty five percent of the natural enemy species are produced in numbers of more than 100,000 per week and are either frequently applied in many of the greenhouse crops (hymenopterans and heteropterans), and/ or need to be released in very large numbers per unit area for sufficient control (acarids and heteropterans).

Microbial pesticides are predominantly used as corrective treatments in greenhouse crops where natural enemies are providing insufficient control, except for the use of Bacillus thuringiensis Berliner (Bacillales: Bacillaceae) against caterpillars which is a standard measure. Fungal microbial control agents against whitefly and thrips are applied locally in hot spots or as blanket treatment besides the use of parasitoids or predators. The same is true for use of baculoviruses against caterpillars. Except for $B$. thuringiensis, the markets for these microbials are relatively small. Insect-pathogenic nematodes are used in ornamental crops, mainly in chrysanthemum, for control of thrips and are then a major part of an IPM programme.

Europe is still the largest commercial market for $\mathrm{ABC}$ with invertebrate biocontrol agents, with a well-functioning, highly developed biocontrol industry. The next largest market is North America, followed by Asia, Latin America, Africa and the Middle East (Dunham 2015; Research and Markets 2016a). According to the latest marketing reports (e.g. Research and Markets 2016b) North America is now the largest market for microbial pesticides, followed by Europe. Since the start of application of biocontrol in greenhouses almost 100 years ago, we see a slow increase in use until the 1970s, followed by a period of strong growth to the year 2000, a stagnation in growth until 2010, with a new period of market expansion of biocontrol today (e.g. van Lenteren et al. 2018a).

\subsection{Biological Control of the Main Groups of Pests}

We do not aim to provide a complete overview of the biology and application methods of biocontrol agents currently used in greenhouses in this chapter. Instead, we will mention the major species that are applied for pest control in greenhouses today, and refer to published information in journals, books and on the world wide web. The number and importance of pest species is changing continuously due to intensified international tourism, trade and transport of crops. Two recent examples of invasive pests spreading all over the world are the South American tomato pinworm Tuta absoluta (Meyrick) (Lepidoptera: Gelechiidae) and the spotted-wing Drosophila, Drosophila suzukii (Matsumura) (Diptera: Drosophilidae). Such new pests initially may very negatively interfere with well working, pesticide independent IPM programmes, but also create research activities resulting in identification and use of new biocontrol agents. For the most recent IPM programmes for various greenhouse crops we refer to the websites of the biocontrol agent producers (Table 14.1) and crop specific chapters in this book. 


\subsubsection{Major Groups of Biocontrol Agents Available for Greenhouse Pest Management}

In Table 14.2 we present the major groups of biocontrol agents used for control of pests in greenhouses. Many other species of beneficial organisms may be used in special situations and for the control of minor pests. Van Lenteren et al. (2018a) provide lists of all agents known for use in $\mathrm{ABC}$, together with the region where used, target pests, first year of use and market value. According to these authors: "The largest European biological control companies are still getting the main part of their income from sales of invertebrate biological control agents, but the contribution of microbial biological control agents is steadily increasing." Commercial ABC is used in protected crops and high-value outdoor crops (e.g. strawberries, grapes), contributing to about $80 \%$ of the market value of invertebrate biocontrol agents. Biocontrol programmes for each of these crops may involve up to 10-20 different species of natural enemies (van Lenteren 2000). Almost $40 \%$ of the income of the European biocontrol companies originates from sales of invertebrate biocontrol agents for control of thrips, another $30 \%$ for control of whitefly, $12 \%$ for control of spider mites, $8 \%$ for control of aphids, and the remaining $10 \%$ for control of various other pests (Bolckmans K, personal communication 2016). We will present the biocontrol agents used in greenhouses per taxonomic group, but not go into detail about their biology. Van der Ent et al. (2017) provide summaries of the biology, behaviour, population development, life cycles, development times at a range of temperatures, photographs and drawings of all natural enemies used in greenhouses, as well extensive information about the pests these natural enemies control.

\subsubsection{Acari}

As of 2005, predatory mites have contributed enormously to the growth of the market for invertebrate biocontrol agents as a result of the (re)discovery of (1) their use for control of whiteflies (e.g. Nomikou et al. 2001), (2) finding more efficient species for thrips control (e.g. Messelink et al. 2006), (3) the development of techniques to enhance dispersal and establishment of predatory mites in crops (e.g. Messelink et al. 2014); and the development of new highly economic massproduction technologies (e.g. Bolckmans et al. 2005). Since the 1960s, Phytoseiulus persimilis, the second commercially available biocontrol agent, was the champion invertebrate natural enemy when expressed in numbers produced per week, but around 2010 Amblyseius swirskii took over the pole position. The following predatory mites are most often used in greenhouse biocontrol (within brackets the year of first use): Amblydromalus limonicus (Garman and McGregor) (Acari: Phytoseiidae) (1995), Amblyseius swirskii (2005), Macrocheles robustulus (Berlese) (Acari: Macrochelidae) (2006), Neoseiulus californicus (1985), Neoseiulus cucumeris (Oudemans) (Acari: Phytoseiidae) (1985), Phytoseiulus persimilis (1968), Stratiolaelaps scimitus (Womersley) (Acari: Laelapidae) (1990) and Transeius 
montdorensis (Schicha) (Acari: Phytoseiidae) (2004). These predatory mites are aimed at reducing populations of phytophagous mites, thrips, whiteflies, dipterans and psyllids (see Table 14.2). Although applied with much success in different crops, several of the important predatory mites species, like A. swirskii, N. californicus and $P$. persimilis, do not perform well on tomato due to the presence of sticky hairs. For a background article about several of the predatory mites mentioned above we refer to McMurtry and Croft (1997).

\subsubsection{Coleoptera}

Ladybird beetles are since long known as efficient predators of many different phytophagous pest insects. Actually, the first "modern" case of very successful biocontrol was obtained by introducing the exotic Australian ladybeetle Rodolia cardinalis (Mulsant) (Coleoptera: Coccinellidae) in the 1880s into the United States of America for control of the invasive cottony cushion scale, Icerya purchasi Maskell (Hemiptera: Monophlebidae). Since its first release, the Rodolia beetle has controlled the Icerya scale pest on citrus worldwide for more than 100 years in more than 50 countries without causing any negative side effect (Cock et al. 2010). Also in greenhouses, several species of ladybird beetles (Coleoptera: Coccinellidae) are used with success, like Adalia bipunctata L. (since 1998), Cryptolaemus montrouzieri Mulsant (1980), Delphastus catalinae (LeConte) (1985) and Rhyzobius lophantae Blaisdell (1980), for control of aphids, mealybugs, scales and whiteflies (Table 14.2). Though not very recent articles, Hagen (1962) and Obrycki and King (1998) are still excellent introductions to the biology of ladybird beetles.

\subsubsection{Diptera}

The gall midge Aphidoletes aphidimyza (Rondani) (Diptera: Cecidomyiidae) has been used in greenhouses for control of aphids since 1989. Gall midge larvae prey on many aphid species. Feltiella acarisuga gall midge larvae, applied in greenhouses since 1990, are specific spider mite predators and used for reducing high density mite concentrations. The syrphid fly Episyrphus balteatus (De Geer) (Diptera: Sirphydae) has been used in greenhouses since the late 1990s for the control of different species of aphids. Recently, Sphaerophoria rueppellii (Wiedemann) (Diptera: Sirphydae) has replaced the use of E. balteatus in some crops (i.e. sweet pepper), because it is adapted to a wider range of temperatures. General information about gall midges can be found in Dorchin (2008).

\subsubsection{Hemiptera}

Hemipteran predators have recently become very popular and important biocontrol agents, although Orius insidiosus (Say) (Hemiptera: Anthocoridae) is already used since the 1980s, and Macrolophus pygmaeus Rambur) (Hemiptera: Miridae) and 
O. laevigatus (Fieber) (Hemiptera: Anthocoridae) are used since the 1990s in greenhouses. These polyphagous predators are applied mainly against thrips, whiteflies, mites, and lepidopterans, but will prey on many other pest species. Currently, Nesidiocoris tenuis (Reuter) (Hemiptera: Miridae) is often used for control of whiteflies and lepidopterans in the Mediterranean area. There is one potential drawback associated with the use of hemipterans, and that is the zoophytophagous behaviour of several species (see Sect. 14.5 of this chapter). An important positive characteristic of the mirid species M. pygmaeus and $N$. tenuis is that they function very well on tomato and have no problem with its sticky hairs (Wheeler and Krimmel 2015). Orius strigicollis (Poppius) (Hemiptera: Anthocoridae) is a recent addition to the list of hemipteran predators and is used for control of thrips. Wheeler (2001) provides background information about hemipteran predators.

\subsubsection{Hymenoptera}

Parasitoid wasps have always been popular biocontrol agents, because of their host specificity. Contrary to many predators, these parasitoids usually attack only a few species and are, therefore, considered safer since they will not parasitize non-target species. Many species of parasitoids are used for pest control in greenhouses. The first commercially available natural enemy for greenhouse use was the whitefly parasitoid Encarsia formosa, which is applied since 1926. The species Eretmocerus eremicus Rose and Zolnerowich (Hymenoptera: Aphelinidae) (since 1995) is also used for whitefly control, in particular to reduce Bemisia tabaci (Gennadius) (Hemiptera: Aleyrodidae) populations. A suite of parasitoids is used for control of aphids, among which the species Aphelinus adbominalis (Dalman) (Hymenoptera: Aphelinidae) (since 1992), and three Aphidius (Hymenoptera: Braconidae) species A. colemani Vierek (1991), A. ervi Haliday (1996), A. matricariae (1980). Often, parasitoids alone are not enough to reduce aphid populations, which is, in part, caused by hyperparasitoids invading the greenhouse and attacking the primary parasitoids listed above. Most important dipteran leafminer species occurring in greenhouses can be successfully controlled with the parasitoids Dacnusa sibirica (since 1981; effective against Liriomyza bryoniae (Kaltenbach) and L. huidobrensis (Blanchard) (Diptera: Agromyzidae)), and Diglyphus isaea (1984, effective against the previously mentioned two species and L. trifolli (Burgess) and L. sativae Blanchard). The parasitoids Anagyrus pseudococci (Girault) (Hymenoptera: Encyrtidae) (since 1995) and Aphytis melinus DeBach (Hymenoptera: Aphelinidae) (1980) are applied against mealybugs and scales, respectively. The heteropteran bug Lygus hesperus Knight (Hemiptera: Miridae) can be controlled with the parasitoid Anaphes iole Girault (Hymenoptera: Mymiridae) (since 1990) and Trissolcus basalis (Wollaston) (Hymenoptera: Scelionidae) can partially reduce populations of Nezara viridula L. (Hemiptera: Pentatomidae) (1995). Trichogramma spp. parasitize eggs and are used since the 1990s for control of various lepidopterans in greenhouses. Godfray's (1994) book entitled "Parasitoids" gives an overview of the biology of parasitoids. 


\subsubsection{Nematoda}

Nematodes that parasitize insects are known from the genera Heterorhabditis and Steinernema, and have been used for control of beetles, lepidopterans, sciarid and shore flies and leaf-mining flies since the 1980s. Killing of the host insect occurs through bacteria that are released into the insect after nematode infection. In greenhouses mainly Heterorhabditis bacteriophora Poinar (Nematoda: Heterorhabditidae) (since 1984) is used for control of various beetle species, and Steinernema carpocapsae (Weiser) (Rhabditida: Steinernematidae) (since 1984) and Steinernema feltiae (Filipjev) (Rhabditida: Steinernematidae) (1984) are applied for control of sciarid and shore flies. A good introduction into the biology and use of entomopathogenic nematodes is provided by Poinar and Grewal (2012).

\subsubsection{Neuroptera}

Many species of Neuroptera, and particularly those of the genus Chrysoperla, are commercially available for biocontrol for control of aphids and whitefly. In greenhouses the species Chrysoperla carnea (Stephens) (Neuroptera: Chrysopidae) is often used for control of aphids since the 1980s. Information on predatory Neuroptera is presented by McEwen et al. (2001).

\subsubsection{Microorganisms}

Microbial control of pests with viruses, bacteria and fungi is a strongly growing market. In greenhouses mainly three species of microbial control agents are often used, while in the field many more species are applied. Information about the biology and commercialization of microbial control agents can be found in Ravensberg (2011).

\section{Bacteria}

The bacterium Bacillus thuringiensis is used since the mid 1980s for control of young lepidopteran caterpillars. The strain B.t. var. israelensis is used on a small scale for control of sciarids.

\section{Fungi}

The fungus Beauveria bassiana (Bals.-Criv.) Vuill. (Hypocreales: Clavicipitaceae) is one of the oldest known entomopathogenic organisms, is applied in greenhouses since the 1990s, and can be used for reduction of populations of a wide array of pests (see Table 14.2). Lecanicillium muscarium Zare \& Gams (Hypocreales: 
Cordycipitaceae), applied since 1980s in greenhouses, is mainly used for control of whitefly, but also kills thrips. Isaria (Paecilomyces) fumosorosea (Wize) Hypocreales: Clavicipitaceae) is solely used for control of whitefly and available since 1999; a second strain reached the market in 2014. Metarhizium anisopliae Sorokin (Hypocreales: Clavicipitaceae) is used for control of black vine weevil and thrips since 2010.

\section{Baculoviruses}

Three species of baculoviruses have been approved for control of noctuid caterpillars (Lepidoptera: Noctuidae) in protected crops: the Spodoptera exigua nucleopolyhydrosis virus against the beet army worm (S. exigua (Hübner)), the Helicoverpa armigera nucleopolyhedrovirus against the cotton boll worm $(H$. armigera (Hübner)), and the Spodoptera littoralis nucleopolyhedrovirus against the cotton leaf worm (S. littoralis (Boisduval)).

\subsection{Searching for and Evaluation of Biological Control Agents}

In this chapter we will not describe the process of collection and evaluation of biocontrol agents in detail. Information concerning these factors for invertebrate biocontrol agents can be found in Cock et al. (2010) and for microbial biocontrol agents in Ravensberg (2011). When searching for natural enemies, it is not unusual to find dozens or more species of predators, parasitoids, parasites and pathogens attacking a certain pest, but criteria such as population growth rate, host range, and adaptation to crop and climate can often be used to quickly eliminate clearly inefficient species (van Lenteren 2010, 2019). Next, the most promising species can be compared by using characteristics such as efficacy of pest control under crop production conditions, potential environmental risks and economy of mass rearing. For the screening of microbial control agents, large collections of hundreds or thousands of isolates may be established for high throughput screening assays to assess important traits such as cold tolerance, metabolite production and efficacy against the target pest. The whole process from searching for potential biocontrol agents up to commercial use may take up to 10 years for invertebrate natural enemies and even longer for microbial control agents, which is particularly due to long registration procedures. Ways to simplify registration of microbials are currently considered in the EU. Due to the recent implementation of the Nagoya Protocol with respect to Access and Benefit Sharing issues, prospecting for exotic biocontrol species has practically come to a stands still and seriously limits finding biocontrol solutions for new invasive pests (see Sect. 14.1 of this chapter). On the other hand, it stimulated searching for native natural enemies which, in some cases, appeared to be able to sufficiently reduce invasive pests. 


\subsection{Mass Production, Storage, Release, and Quality Control of Biological Control Agents}

About 500 companies commercially produce invertebrate biocontrol agents worldwide, although most of these employ a handful of personnel. Less than ten producers employ more than 50 staff. In addition to commercial producers, there are hundreds of government-owned production units, particularly in China, India and Latin America. Also, and especially in Latin America, some large-scale growers are involved in producing their own natural enemies. Together, these companies and grower or government-owned production facilities produce at least 350 species of invertebrate natural enemies and 209 strains from 94 different species of microbial control agents (van Lenteren et al. 2018a). Microbial biocontrol agents are produced by approximately 200 manufacturers, which is an underestimate as no data are available for China or India (Dunham 2015). Companies, the majority of which are small to medium sized, are often specialised in one or two types of microorganisms and production methods. Large multinational agro-chemical companies are now getting involved in the production and marketing of microbial control agents, mainly through the acquisition of the small to medium-sized companies.

Since the 1970s, ABC has moved from a cottage industry to professional research and production facilities. Since then, many efficient agents have been identified, quality control protocols, mass-production, shipment and release methods matured, and adequate guidance for farmers has been developed (van Lenteren 2003, 2012; Cock et al. 2010; Ravensberg 2011). Mass production of natural enemies is described in detail in various chapters in van Lenteren (2003), including obstacles encountered in setting up and running large scale rearing programmes, mass-production schemes, storage procedures, methods for collection, shipment and release of natural enemies, and quality control techniques and protocols. All the elements related to mass production just mentioned have undergone a very fast development since the 1970s. Not only are many more species and much higher numbers produced per week, also mass-rearing methods have been developed that are no longer based on rearing on the target pest and target crop, but on other hosts or prey species and inert substrates (see e.g. Bolckmans et al. 2005). These improvements have led to a decrease in price of several important biocontrol agents. Shipment in climate controlled containers, development of slow release sachets for natural enemies and mechanized delivery methods (see e.g. Lanzoni et al. 2017) have all resulted in improved biocontrol results in greenhouses. Still, there is great demand for cheaper ways of mass production, strongly improved methods for natural enemy storage during longer periods and with better survival, and for simpler and more reliable quality control protocols. For massproduction, storage, application methods and quality control of microbial control agents, we refer to Ravensberg (2011). 


\subsection{Recent Popularity of Polyphagous Predators: Pros and Cons}

Historically, the development of biocontrol in greenhouses has been characterized by using specialized natural enemies, mainly parasitoids (see introduction of this paper). However, during the development of biocontrol programmes in southern Europe the spontaneous presence of generalist predators was often observed, mainly of mirids in tomato greenhouses (Fauvel et al. 1987; Albajes et al. 1980; Arnó et al. 2018). Initially, they were considered with scepticism, because of being generalists they might cause unwanted side effects by preying on other beneficial insects. Nevertheless, experience has shown during the past decades that generalists can be effective biocontrol agents under many circumstances (DeClerq 2002; Symondson et al. 2002). Their polyphagy is in a number of situations even advantageous as it allows them to survive when the target pest is reduced to low densities, which is to supposed to happen in successful biocontrol programmes (Albajes and Alomar 1999). Nowadays, generalist predators are recognized to be valuable biocontrol agents and several of them have been incorporated successfully into the portfolio of biocontrol agents (see Table 14.1 and Sect. 14.2 of this chapter and see other chapters in this book). Several of the generalist predators used in greenhouse biocontrol are also omnivores (or zoophytophages). They not only feed on animal prey, but complement or supplement their nutritional needs profiting from plant resources (pollen, nectar, seeds or plant juices). Further to this, plant tissues (phloem and xylem) may provide a source of water as well as nutrients. Overall phytophagy in predators results in improved life-history traits such as survival, development time, fecundity and longevity (Coll and Guershon 2002; Wäckers et al. 2005; Albajes and Alomar 2008). A well-known example of a positive effect of phytophagy is the requirement of pollen for the establishment of Orius predators.

Omnivory may actually make these predators preferred candidates for effective pest control, because plant feeding allows them to survive and bridge periods of low pest presence. As a consequence, they may establish on crops early in the growing season when prey is scarce or absent. This enables them to respond quickly to new pest infestations. Additionally, it may contribute to sustain predator populations while target pests are under control and occur at very low densities. At present, the positive effects of the ability to feed on plants is well acknowledged, and non-crop plants may be added to the crop to improve the presence and establishment of predators. Not only do these non-crop plants offer shelter or alternative food, but they also provide breeding sites for development of predator populations (Messelink et al. 2014; Perdikis et al. 2011; Lambion et al. 2016). In practice however, few growers use such plants.

Probably the most successful example of using polyphagous predators in greenhouses is the combined use of the predatory mite A. swirskii together with the anthocorid $O$. laevigatus in protected sweet peppers (see chapter 18). If properly managed, release and conservation of both natural enemies can successfully reduce 
populations of the key pepper pests; sweet potato whitefly, B. tabaci, greenhouse whitefly, T. vaporariorum and western flower thrips, Frankliniella occidentalis (Pergande) (Thysanoptera: Thripidae) (Sanchez and Lacasa 2002; Calvo et al. 2012a; van Lenteren 2012; van Lenteren et al. 2018a). Moreover, the polyphagous behaviour of $A$. swirskii and $O$. laevigatus contributes to the management of secondary pests, such as spider mites and Lepidoptera (Park et al. 2010; van Maanen et al. 2010). The use of these two predators in sweet pepper in Murcia and Almería (Southeast Spain) is a paradigmatic example: the area under biocontrol increased from a mere 200 ha in the 2005-2006 season to about 7,500 ha in 2008-2009, and in the 2015-2016 season the area exceeded 10,000 ha (almost 100\% of the sweet pepper aea) (Calvo et al. 2015; van der Blom 2017).

Amblyseius swirskii is native to the Mediterranean-Middle East area and is commercially available as a biocontrol agent of whitefly and thrips in different crops since 2005 (Nomikou et al. 2001, 2002; Messelink et al. 2008; Calvo et al. 2011, 2015). In Spain alone, during the 2012-2013 season, the total greenhouse area sunder biocontrol using $A$. swirskii reached 18,000 ha (Calvo et al. 2015). The ability of $A$. swirskii to establish even before the appearance of the pest, owing to its capability of feeding on alternative food sources such as pollen, nectar, small insects and mites as T. urticae and Polyphagotarsonemus latus (Banks) (Acari: Tarsonemidae) and other non-prey food, including eggs of the Mediterranean flour moth Ephestia kuehniella Zeller (Lepidoptera: Pyralidae), decapsulated dry cysts of the brine shrimp Artemia franciscana Kellogg (Anostraca: Artemiidae), enhanced its efficiency as biocontrol agent.

Orius laevigatus is a key predator of thrips, but also preys on B. tabaci (Chambers et al. 1993; Hamdan and Abu-Awad 2008). In addition, O. laevigatus can consume other arthropod pests such as aphids and mites (Alvarado et al. 1997; Venzon et al. 2002). The generalist anthocorid predator O. laevigatus, is a western Palaearctic species, widespread along Mediterranean and Atlantic coasts (Tommasini 2004). Many characteristics contribute to its success, including the absence of diapause, high fecundity, a long life span and polyphagy (Tommasini and Nicoli 1996; Tommasini et al. 2004). Like many other anthocorids, the predator O. laevigatus is also able to exploit plant resources, including pollen and plant juices, and use the plant as egg-laying substrate (Cocuzza et al. 1997; Lattin 1999). Adults may feed on mesophyll and xylem, and Lundgren et al. (2008) reported that neonate O. insidiosus were able to feed on the nutritious phloem, allowing them to survive on plant materials for several days. Feeding from plants by anthocorids helps predator establishment and survival when protein-rich animal food lacks. Until today plant-feeding by Orius has not resulted in complaints by growers such as in the case of $N$. tenuis, but it is an interested phenomenon deserving further study. Recently Bouagga et al. (2018a) investigated the importance of $O$. laevigatus feeding on sweet pepper compared to other behaviour: it spends almost $40 \%$ of its time on feeding, mainly on apical meristems and apical fresh leaves, which are also favourite residence locations. This information indicates that plant feeding is common and ecologically relevant for omnivorous Orius bugs. 
Biocontrol by predatory mirids in greenhouses is another example of successful use of omnivorous, plant-feeding species. One of these mirid species, Macrolophus pygmaeus, spontaneously colonizes tomato crops where IPM is used, and contributes to the control of several important pests, including whiteflies, aphids, thrips, mites, leafminers and moths. This mirid species now has been used in commercial greenhouse tomato production in Europe for almost 30 years. When spontaneous presence is not sufficient, releases are made, primarily to control whiteflies and the exotic tomato leaf miner Tuta absoluta. Yet, under specific circumstances, plantfeeding by predatory mirids may cause injury to the crop, which does not necessarily have to result in yield loss when injury is limited. Injury is predator species and crop specific, and may vary dependent on crop species and variety, growth stage and affected plant part (Castañe et al. 2011). In many cases the injury zoophytophagous mirids may cause to the crop phytophagy was compensated by their beneficial value as pest control agent (Gabarra et al. 1988). In fact, M. pygmaeus has been said to cause some yellowish discoloration and deformed tomato fruits, especially at extremely high population levels resulting from too high initial release rates and application of adding supplementary food too frequently (Moerkens et al. 2016), but this has not stopped it from being used on a large scale all over Europe. Albajes et al. (2006) provide guidance as to how to assess risk of damage.

Another group of successfully used zoophytophagous mirids are Dicyphus (Hemiptera: Miridae) species, and also here the fact that they may feed on plants does not prohibit their application. Dicyphus tamaninii Wagner is spontaneously present in field and greenhouse crops, and injury to tomato fruits only arose when excessive predator populations were observed after controlling high whitefly densities (Gabarra et al. 1988). Injury might result in economic damage due to yield reduction, requiring measures to control high densities of the predator. Development of decision thresholds related to predator-prey ratios avoided the appearance of injury in commercial fields after pests were controlled (Alomar and Albajes 1996). The above reported results highlight the success of proper strategies to manage natural populations of mirids for successful biocontrol. Dicyphus errans (Wolff), another zoophytophagous mirid, occurs naturally and is the most abundant dicyphine in tomato crops in Northwestern Italy. It is considered a major contributor to the control of Tuta absoluta. A strategy to manage D. errans populations in greenhouses now aims to identify specific companion plants that either boost predator populations but not the pest T. absoluta, or to control T. absoluta on the companion plants during the off-season period (Ingegno et al. 2017). Both Dicyphus species have not yet been commercialized, but are under evaluation for use in several crops (Messelink et al. 2015). Two other European species, D. geniculatus (Fieber) (Beitia et al. 2016) and D. maroccanus (Wagner) (Abbas et al. 2014) are currently tested for their pest control capacity. Dicyphus hesperus Knight was identified as an effective natural enemy of whitefly and spider mites in Canadian greenhouses (Gillespie et al. 2007), and was later used to control several other pests in tomato. It does not damage fruits unless its numbers are high and prey density is low. Recently Calvo et al. (2016) have been looking at the potential of $D$. hesperus to control new invasive pests, such as the potato psyllid Bactericera cockerelli (Šulc) (Hemiptera: 
Triozidae). Other recent activities concern the evaluation and use of three Neotropical mirids (Hemiptera: Miridae), Campyloneuropsis infumatus Carvalho, Engytatus varians Distant and Macrolophus basicornis Stål, for control of various lepidopteran pests and whiteflies in greenhouse tomatoes in Brazil (Bueno et al. 2013) and, interestingly, during laboratory and greenhouse tests these three mirids seem to cause much less plant and fruit injury than the two commercially used European mirids (Silva et al. 2017; van Lenteren et al. 2018b).

Another important zoophytophagous mirid used for biocontrol in greenhouses is Nesidiocoris tenuis. This predator was not native to Europe, but invaded the Mediterranean area in 1985, spontaneously colonized greenhouses and contributed to pest control (Pérez-Hedo and Urbaneja 2016). In some Mediterranean regions $N$. tenuis has become an important player in the battle against whitefly and Tuta absoluta, and, in most cases, the benefits of pest reduction outweigh plant damage. In areas where M. pygmaeus does not establish well, $N$. tenuis has been mass reared, commercialized, and released with success, and several commercial biocontrol companies offer $N$. tenuis in their portfolio. Indeed, tomato production in Southeast Spain is currently managed using $N$. tenuis as the main pest control method, and T. absoluta is a major problem on tomatoes when $N$. tenuis is not released. In other parts of Europe this bug is considered a problem, especially after pest control has been achieved with $M$. pygmaeus. Its plant-feeding results in necrotic rings on the stem, shoots, leaf petioles and flower stalks, that may cause abortion of flowers and young fruit and reduced growth of the plant. Serious injury is observed with large $N$. tenuis populations in the crop, when few or no prey is available, and specially on sensitive crops and varieties, like cherry tomatoes and small-truss tomato types. In France, entomopathogenic nematodes are advised for control of $N$. tenuis resulting in significant reduction of mirid populations and plant damage (https://www.koppert.fr/conseils-de-culture/gamme-nematodes-gel-koppert-de-nouvelles-ciblesdans-le-viseur-des-biosolutions/). Nesidiocoris tenuis mainly preys on the eggs of T. absoluta, which means that preventive releases have to be made to ensure T. absoluta control as soon as the pest appears (Calvo et al. 2012b). Due to slow establishment when weather conditions are not favourable during winter, $N$. tenuis is also released in seedling nurseries before the transplant. This shortens the establishment period, and improves the distribution of the predator in the crop. Such pre-transplant releases may influence biocontrol even in other ways than direct predation on the pest. Puncturing of plants by these zoophytophagous bugs can induce defence related responses that reduce the performance of other herbivores and may also attract other natural enemies (see next section of this chapter). And this, again, shows that generalist, omnivorous predators should not be classified simply as bad or good. Careful study of positive and negative impacts, and next, a well-balanced evaluation of effects may result in proper use of mirid predators and enhance sustainability in pest control (Pappas et al. 2016; Bouagga et al. 2018b).

The success of zoophytophagous mirids in biocontrol programmes in European greenhouses resulted in increasing interest in the search for these mirids as candidates for biocontrol of pests outside Europe (van Lenteren et al. 2016; Silva et al. 


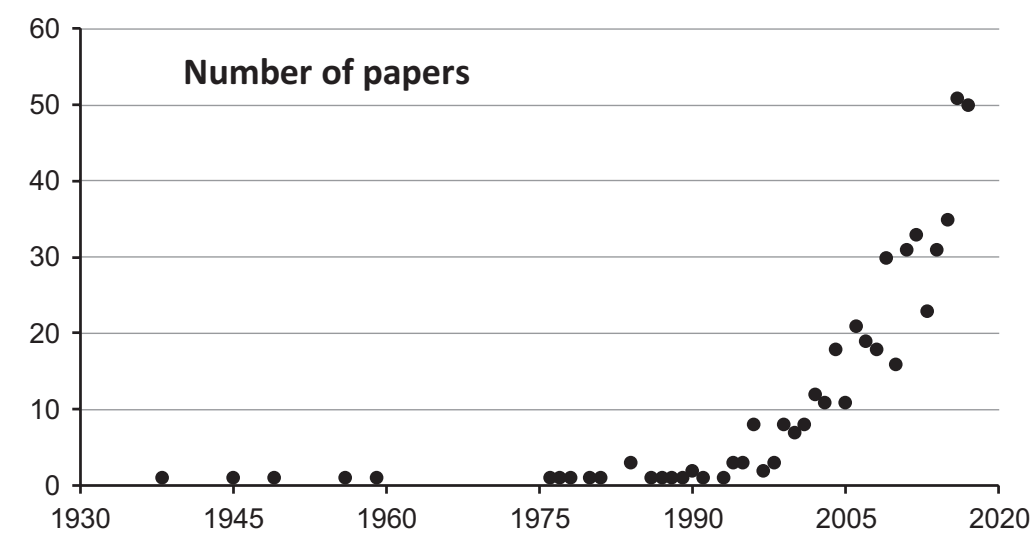

Fig. 14.3 Number of papers indexed in the Web of Science that include the search terms 'Macrolophus', 'Dicyphus' or 'Nesidiocoris'

2017; Pineda et al. 2016). Overall, the number of research papers that appear in the Web of Science mentioning either 'Macrolophus', 'Dicyphus' or 'Nesidiocoris' has steadily increased since early work with mirids on tomato published in France and Spain (Fauvel et al. 1987; Gabarra et al. 1988) (Fig. 14.3).

Most papers are related to the assessment of new species, testing them in crops, and to basic research on plant-feeding habits etc., but not so much on how to control them when considered 'pests'. This highlights to what extent their management is considered beneficial within IPM programmes. Still, when an omnivorous predator species may pose a risk of injury to the target crop, any measure promoting their establishment, augmentation or persistence should be carefully tested in order to avoid excessive predator populations at critical times during the cropping period. Unrestricted augmentation strategies may facilitate migration between successive or neighbouring crops (Castañe et al. 2004), thereby enhancing the risk that recently transplanted crops may receive too high populations. Conversely, screens used to avoid pest entrance may also concentrate too high predator populations in the greenhouse. In addition, too frequent use of supplemental foods may result in fast population growth and damage (Moerkens et al. 2016). Further, banker or companion plants should be selected or managed in such a way that they are useful for the target predator (e.g. M. pygmaeus), but less so for less desirable species (e.g. N. tenuis).

In order to optimize pest control while minimizing plant damage, more research is needed on the mechanisms behind the effects of feeding behaviour of these zoophytophagous species. Of particular interest is the effect of plant feeding on plant quality for herbivores (induced resistance), and on attraction and repellence of herbivores and predators/parasitoids (Durán-Prieto et al. 2017). 


\subsection{Use of Semiochemicals in Greenhouse IPM}

Although application of semiochemicals is not strictly considered a form of biocontrol (the use of a population of one organism to reduce the population of another organism), these chemicals might play an important role in increasing the efficacy of natural enemies. Communication among arthropods and between arthropods and their surrounding ecosystem is for a large part based on chemical information. Knowledge about chemical communication in insects has increased enormously during the past 70 years and some of the findings are used in greenhouse IPM. Chemical compounds playing a role in communication between organisms are generally addressed as semiochemicals (Vet and Dicke 1992).

One group of semiochemicals has been used in agriculture since the 1970s: insect pheromones (Baker 2009). A pheromone is a chemical compound that evokes a responses in an organism of the same species and they often play a role in communication between the sexes. The composition of many of these sex pheromones has been analysed and can be synthetically produced. Pheromones are applied in agriculture to discover whether pests are present (monitoring technique), to attract and trap pest insects (mass-trapping technique), or to confuse communication by releasing pheromones in such concentrations that sex partners can no longer find each other (mating disruption technique). In greenhouses, mainly the monitoring technique is used, for example to detect the presence of several lepidopteran pests (e.g. Tuta absoluta, and several noctuids (Lepidoptera: Noctuidae) as Chrysodeixis chalcites (Esper), Lacanobia oleracea (L), Ostrinia nubilalis (Hübner), and Spodoptera exigua (www.biobest.be, www.koppert.com). The mass-trapping technique is used for control of T. absoluta (www.koppert.com). Interestingly, natural enemies of pests can spy on the sexual communication used by pest insects. They use the sex pheromone to detect if and where pest insects are present (e.g. Fatouros et al. 2008), but this knowledge is not yet commercially applied. In this case, the pheromone is used by the parasitoid as a kairomone, because not the emitting organism (the pest producing the pheromone) is benefitting, but an organism of another species, the parasitoid.

Natural enemies use chemical compounds of other natural enemies, pests, plants and other players in (agro-) ecosystems in many different ways to obtain information on the presence of refugia, food or hosts for reproduction. In this paragraph we concentrate on the effects of chemical information produced by plants, particularly after they have been attacked by pests. Plants have evolved with different types of defense mechanisms to minimize attack by phytophagous pests. These defenses can, among other phenomena, cause the production of secondary metabolites and proteins that have toxic, repellent and/or anti-nutritive effects on herbivores (direct defenses) (Kant et al. 2015), and these chemical compounds are then addressed as allomones, because they benefit the emitter of the volatile - the plant - but not the receiver, the herbivore. Furthermore, production and release of plant volatiles (Herbivore Induced Plant Volatiles; HIPVs) is triggered by attack of plant-eating arthropods, and this can modify the behaviour of both phytophagous pests and their 
natural enemies (indirect defenses) (Dicke 2016). These plant volatiles, such as the green leaf volatiles (GLVs) and others as terpenoids, play an important role in signaling information for natural enemies to be attracted to the damaged plant (Peterson et al. 2016), and in this case we speak about synomones, because the volatiles produced by the plant are benefitting both the emitter, the plant, and an organism of a different species, the natural enemy. Therefore, HIPVs, if properly managed, could offer an excellent tool to increase the presence of natural enemies in crops. There are two possible ways in which the use of HIPV's could attract and promote natural enemies within a greenhouse crop: (i) intercropping plant species that emit endogenously HIPV's and (ii) applying exogenously HIPV's on the crop. Conservation biocontrol strategies based on endogenously and exogenously HIPV's have been tested mainly in outdoor crops with promising results (James 2005; Mallinger et al. 2011). However, few studies concern greenhouse crops, while we expect this approach could be even more exploited than in outdoor crops. Recently, several studies indicated that HIPV's might already be playing an important role in the pest management of several horticultural crops where zoophytophagous predators are actively used. Pérez-Hedo et al. (2015) demonstrated that phytophagy by the mirid predators $N$. tenuis and $M$. pygmaeus activated the metabolic pathway of jasmonic acid (JA) in tomato, which made them more attractive to the whitefly parasitoid Encarsia formosa. The HIPVs involved in the defensive responses of tomato induced by $M$. pygmaeus and $N$. tenuis and responsible for parasitoid attraction have been identified: six green leaf volatiles (GLVs) and methyl salicylate (Pérez-Hedo et al. 2018). In general, plants exposed to $N$. tenuis emitted more volatiles than plants exposed to $M$. pygmaeus. In sweet pepper, phytophagy by the anthocorid predator $O$. laevigatus also triggers defensive responses and also here E. formosa attraction is induced; $O$. laevigatus attack results in the release of a mixture of volatiles (5 terpenes, 2 GLV's, methyl salicylate and one to be identified) and the activation of the JA and salicilic acid (SA) metabolic pathways (Bouagga et al. 2018a). Also phytophagy by $N$. tenuis and $M$. pygmaeus in sweet pepper caused attraction of $E$. formosa and resulted in production of volatiles similar to those produced by O. laevigatus (Bouagga et al. 2018b). Altogether these results show how the plant's response to zoophytophagous predators increases emission of HIPV's which can modulate the behaviour of other arthropods, both pests and natural enemies. Indeed, these induced defenses could partially explain the great success achieved by IPM programmes based on the release, establishment and conservation of zoophytophagous predators in crops as sweet peppers and tomatoes (Fig. 14.4). Some authors recommend the use of zoophytophagous predators as vaccines, so that releases of these predators on seedlings can activate the the defense mechanism of the plants at the moment of transplantation to the greenhouse (Pappas et al. 2015; Bouagga et al. 2018b). Furthermore, because some HIPV's might be elicitors of the induction of indirect defenses in horticultural crops, recent results have demonstrated that activation of JA pathway in intact tomato plants is possible by simply exposing them to a HIPV of synthetic origin (Pérez-Hedo et al. personal communication). Therefore, imitating the defenses induced by zoophytophagous predators with elicitors of synthetic origin may be an effective natural alternative to induce defenses in 


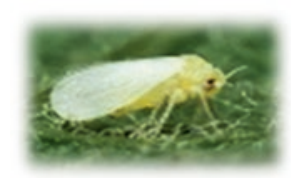

Herbivore Bemisia tabaci

\section{Repellency}

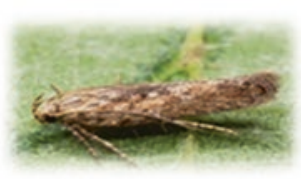

Herbivore Tuta absoluta

Repellency

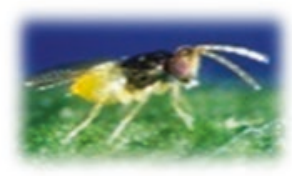

\section{Parasitoid}

Encarsia formosa

\section{Attraction}

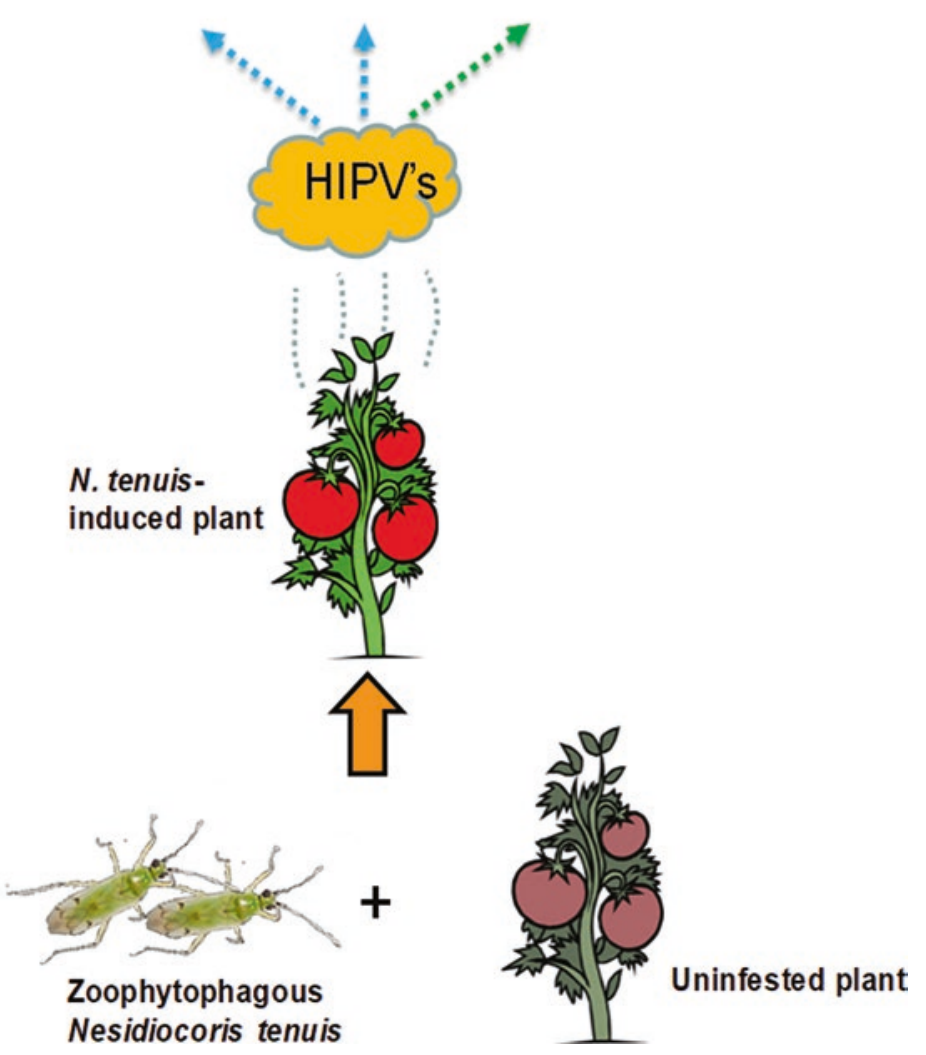

Fig. 14.4 A conceptual model of how HIPV's triggered by the zoophytophagous predator Nesidiocoris tenuis can attract or repel arthropods. In the model, an uninfested tomato plant is activated by $N$. tenuis feeding. Activated plants produce HIV's resulting in (i) a repellent effect on the whitefly Bemisia tabaci and the lepidopteran Tuta absoluta, and (ii) in attraction of the whitefly parasitoid Encarsia formosa. (Adapted from Pérez-Hedo et al. 2015)

greenhouse crops. Finally, the rapid advance of gene editing technology allows us to speculate that in a future not too far away the production of plants with an increased ability to attract natural enemies after pest attack will be possible (Gurr and You 2016). 


\subsection{Future Developments of Biological Control of Greenhouse Pests}

We are very positive about the future of biocontrol in greenhouses. Growth percentages for sales of biocontrol agents have during the past 10 years been considerably higher than for conventional synthetic pesticides (Dunham 2015) and this is for a large part due to the inherent positive characteristics of biocontrol agents. These agents are basically harmless to the health of farm workers and persons living in farming communities. Also, they do not have a harvesting interval or re-entry period as do pesticides. Further, they are more sustainable, as there has been no development of resistance against arthropod $\mathrm{ABC}$ agents. In addition, the large majority of biocontrol agents do not cause phytotoxic damage to plants and, as a result, most farmers report better yields and healthier crops after switching to biocontrol-based IPM. Consumers continue to express concerns about food safety and environmental impact issues in relation to synthetic pesticide use. Food retailers and supermarkets often have stricter demands about pesticide use and MRL levels than governments do. The current EU approach to stimulate development and adoption of IPM programmes, in which biocontrol is a cornerstone, has increased interest in and application of ABC (Lamichhane et al. 2017). The decision by the EC (2009) that a large number of pesticides will be legally discontinued will also lead to increased requests for $\mathrm{ABC}$ solutions. The development of new and better biocontrol solutions during the past decades, improved and more stable formulations for microbial biocontrol agents and their use as seed treatments, and more convenient application methods for invertebrate biocontrol agents have resulted in increased respect for biocontrol as a reliable alternative for synthetic pesticides. More important, biocontrol provides a solution for quite a number of pests in greenhouses that can no longer be controlled with synthetic pesticides due to lack of efficacy and development of resistance. Moreover, biocontrol agents are usually the only option for real IPM programmes and in many cases displaced failing chemical pest control.

There are, however, also developments that may hamper or delay implementation of biocontrol in IPM. We have already mentioned the increased regulatory requirements and the strongly negative effects of the implementation of the Nagoya protocol concerning Access and Benefit Sharing issues. We are, of course, in favour of the fair and equitable sharing of benefits arising from the utilization of genetic resources, but implementation of the protocol without availability of clear guidelines has resulted in a bureaucratic nightmare for researchers. International harmonization of regulations concerning environmental risk analyses and registration would result in faster implementation and lower costs of biocontrol agents. The following might be a surprising statement for many, but also researchers may frustrate implementation of biocontrol by publishing "immature or speculative" papers stating that their findings show as a result of laboratory research under highly standardized conditions that certain natural enemies are very promising candidates for biocontrol. We agree with Brownbridge (2017) that: "True measures of performance (- of a natural enemy, authors -) need to be done with this framework (- the produc- 
tion environment, authors -) in mind and the contribution and fit of the biocontrol agent considered within a defined production system. ... Yet bridging the gap between discovery to implementation and integration is critical to the broader uptake of biologically-based IPM. .... Studies should be designed to duplicate commercial environments and data interpreted using appropriate statistical analyses" (end of quote).

On the positive side, there are also research developments aiming to result in improved practical biocontrol, such as the BINGO project, whose main objective is to deliver improved biocontrol agents genetically selected for optimal trait values (https://subsites.wur.nl/en/bingo.htm). This would allow to improve the efficacy of these natural enemies obtained through selective breeding in a broad range of agricultural systems and environmental conditions (Lommen et al. 2018).

Finally, those working in practical biocontrol of arthropod pests are hoping for several contributions from those working in pure and applied science. First, improvement of methods for finding and quick evaluation of natural enemies is of high priority (Ravensberg 2011; van Lenteren et al. 2019). Currently, still a lot of time is spent on studying potential candidates that appear to be inefficient after having spent a considerable amount of time and money. Fast, but meaningful evaluation methods would be very helpful in speeding up the trajectory from discovery to marketing (van Lenteren et al. 2019). Secondly, perfection of quality control protocols is needed (van Lenteren 2003). Some of the presently used quality criteria are not really telling a lot, others that do so are often time consuming. A simple to determine, but reliable characteristic would be appreciated. Thirdly, progress in storage methods is of great importance as most arthropod can only be stored for a few days without loss in performance. Finally, methods and equipment for large scale release without quality loss of the natural enemies are essential, but this problem might be solved rather quick as developments in the field of mechanical distribution and releases with drones are fast.

Acknowledgements Dr. A.J.M. Loomans (The Netherlands food and consumer product safety authority (NVWA)) and Dr. M. Knapp (Koppert Biological Systems, The Netherlands) are thanked for helping us updating the list of recently marketed exotic and native biological control agents in Europe.

\section{References}

Abbas S, Pérez-Hedo M, Colazza S, Urbaneja A (2014) The predatory mirid Dicyphus maroccanus as a new potential biological control agent in tomato crops. BioControl 59:565-574

Albajes R, Alomar O (1999) Current and potential use of polyphagous predators. In: Albajes R, Gullino ML, van Lenteren JC, Elad Y (eds) Integrated pest and disease management in greenhouse crops. Kluwer Academic Publishers, Dordrecht, pp 265-275

Albajes R, Alomar O (2008) Facultative predators. In: Capinera JL (ed) Encyclopedia of entomology. Springer, Dordrecht, pp 1400-1405 
Albajes R, Casadevall M, Bordas E, Gabarra R, Alomar O (1980) La mosca blanca de los invernaderos, Trialeurodes vaporariorum, en El Maresme. II. Utilización de Encarsia tricolor [Hym.: Aphelinidae] en un invernadero de tomate temprano. Anales INIA/Ser Agric 13:191-203

Albajes R, Gullino ML, van Lenteren JC, Elad Y (eds) (1999) Integrated pest and disease management in greenhouse crops. Kluwer Publishers, Dordrecht. 545 pp

Albajes R, Castañé C, Gabarra R, Alomar O (2006) Risks of plant damage caused by natural enemies introduced for arthropod biological control. In: Bigler F, Babendreier D, Kuhlmann U (eds) Environmental impact of invertebrates for biological control of arthropods: methods and risk assessment. CABI Publishing, Oxon, pp 132-144

Alomar O, Albajes R (1996) Greenhouse whitefly (Homoptera: Aleyrodidae) predation and tomato fruit injury by the zoophytophagous predator Dicyphus tamaninii (Heteroptera: Miridae). In: Alomar O, Wiedenmann RN (eds) Zoophytophagous Heteroptera: implications for life history and integrated pest management. Entomological Society of America, Lanham, pp 155-177

Alvarado P, Balta O, Alomar O (1997) Efficiency of four heteroptera as predators of Aphis gossypii and Macrosiphum euphorbiae (Hom.: Aphididae). Entomophaga 42:215-226

Arnó J, Castañé C, Alomar O, Riudavets J, Agustí N, Gabarra R, Albajes R (2018) Forty years of biological control in Mediterranean tomato greenhouses: the story of success. Isr J Entomol 48(2):209-226

Baker TC (2009) Use of pheromones in IPM. In: Radcliffe EB, Hutchison WD, Cancelado RE (eds) Integrated pest management. Cambridge University Press, Cambridge UK, pp 273-285

Beitia F, Asís JD, Pedro LD, Goula M, Tormos J (2016) Importance of feeding behaviour on life cycle in the zoophytophagous bug Dicyphus geniculatus. Bull Insectology 69(2):173-180

Bigler F, Babendreier D, Kuhlmann U (2006) Environmental impact of invertebrates for biological control of arthropods: methods and risk assessment. CAB Int, Wallingford, 299 pp.

Bolckmans KJF, Houten YM, Van Baal AE, Castagnoli M, Nannelli R, Simoni S (2005) Mite composition comprising Glycyphagidae and phytoseiid mites, use thereof, method for rearing a phytoseiid predatory mite, rearing system for rearing said phytoseiid predatory mite and methods for biological pest control on a crop. Patent registered as PCT/NL2005/000899, Priority date: December 29, 2005

Bouagga S, Urbaneja A, Rambla JL, Granell A, Pérez-Hedo M (2018a) Orius laevigatus strengthens its role as a biological control agent by inducing plant defenses. J Pest Sci 91:55-64

Bouagga S, Urbaneja A, Rambla JL, Flors V, Granell A, Jaques JA, Pérez-Hedo M (2018b) Zoophytophagous mirids provide pest control by inducing direct defences, antixenosis and attraction to parasitoids in sweet pepper plants. Pest Manag Sci 74(6):1286-1296

Brownbridge M (2017) Biological control in greenhouse IPM systems: where we've been, where we are, and where we need to go? IOBC-WPRS Bull, Bull OILB-SROP 124:1-11

Bueno VHP, van Lenteren JC, Lins JC Jr, Calixto AM, Montes FC, Silva DB, Santiago LD, Pérez LM (2013) New records of Tuta absoluta (Meyrick) (Lepidoptera: Gelechiidae) predation by Brazilian hemipteran predatory bugs. J Appl Entomol 137:29-34

Calvo FJ, Bolckmans K, Belda JE (2011) Control of Bemisia tabaci and Frankliniella occidentalis in cucumber by Amblyseius swirskii. BioControl 56:185-192

Calvo FJ, Bolckmans K, Belda JE (2012a) Biological control-based IPM in sweet pepper greenhouses using Amblyseius swirskii (Acari: Phytoseiidae). Biocontrol Sci Tech 22:1398-1416

Calvo FJ, Lorente MJ, Stansly PA, Belda JE (2012b) Preplant release of Nesidiocoris tenuis and supplementary tactics for control of Tuta absoluta and Bemisa tabaci in greenhouse tomato. Entomol Exp Appl 143:111-119

Calvo FJ, Knapp M, van Houten YM, Hoogerbrugge H, Belda JE (2015) Amblyseius swirskii: what made this predatory mite such a successful biocontrol agent? Exp Appl Acarol 65:419-433

Calvo FJ, Torres-Ruiz A, Velázquez-González JC, Rodríguez-Leyva E, Lomeli-Flores JR (2016) Evaluation of Dicyphus hesperus for biological control of sweet potato whitefly and potato psyllid on greenhouse tomato. BioControl 61:415-424

Castañé C, Alomar O, Goula M, Gabarra R (2004) Colonization of tomato greenhouses by the predatory mirid bugs Macrolophus caliginosus and Dicyphus tamaninii. Biol Control 30:591-597 
Castañé C, Arnó J, Alomar O (2011) Plant damage to vegetable crops by zoophytophagous mirid predators. Biol Control 59:22-29

Cavalloro R, Pelerents C (1989) Integrated pest management in protected vegetable crops. Balkema, Rotterdam. 416 pp

Chambers R, Long S, Helyer NL (1993) Effectiveness of Orius laevigatus (Hem, Anthocoridae) for the control of Frankliniella occidentalis on cucumber and pepper in the UK. Biocontrol Sci Tech 3:295-307

Cock MJW, van Lenteren JC, Brodeur J, Barratt BIP, Bigler F, Bolckmans K, Cônsoli FL, Haas F, Mason PG, Parra JRP (2010) Do new access and benefit sharing procedures under the convention on biological diversity threaten the future of biological control? BioControl 55:199-218

Cocuzza GE, De Clercq P, Van de Veire M, De Cock A, Degheele D, Vacante V (1997) Reproduction of Orius laevigatus and Orius albidipennis on pollen and Ephestia kuehniella eggs. Entomol Exp Appl 82:101-104

Coll M, Guershon M (2002) Omnivory in terrestrial arthropods: mixing plant and prey diets. Annu Rev Entomol 47:267-297

DeClerq P (2002) Dark clouds and their silver linings: exotic generalist predators in augmentative biological control. Neotrop Entomol 31:169-176

Dicke M (2016) Plant phenotypic plasticity in the phytobiome: a volatile issue. Curr Opin Plant Biol 32:17-23

Dorchin N (2008) Gall midges (Diptera: Cecidomyiidae). In: Capinera JL (ed) Enclyclopedia of entomology, vol 2. Springer, Dordrecht, pp 1576-1580

Dunham WC (2015) Evolution and future of biocontrol. Paper presented at the 10th Annual Biocontrol Industry Meeting (ABIM), Basel, Switzerland, October 20th, 2015. http://www. abim.ch/index.php?eID=tx_nawsecuredl\&u=0\&g=0\&t=1489234639\&hash=9a70d39f93f7e5 59c74c63844ae047a9aa3c37ea\&file=fileadmin/abim/documents/presentations2015/Keynote_ Dunham_ABIM_2015.pdf. Cited 10 March 2017

Durán-Prieto J, Castañe C, Calvet C, Camprubi A, Battaglia D, Trotta V, Fanti P (2017) Tomato belowground - aboveground interactions: Rhizophagus irregularis affects foraging behavior and life history traits of the predator Macrolophus pygmaeus (Hemiptera: Miridae). Arthropod Plant Interact 11:15-22

EC (2009) Sustainable use directive. European Parliament and of the Council of 21 October 2009 establishing a framework for community action to achieve the sustainable use of pesticides. Off J Eur Union L309:71-86

Fatouros NE, Dicke M, Mumm R, Meiners T, Hilkers M (2008) Foraging behavior of egg parasitoids exploiting chemical information. Behav Ecol 19:677-689

Fauvel G, Malausa JC, Kaspar B (1987) Etude en laboratoire des principales caracteristiques biologiques de Macrolophus caliginosus (Heteroptera: Miridae). Entomophaga 35:529-543

Gabarra R, Castañé C, Bordas E, Albajes R (1988) Dicyphus tamaninii as a beneficial insect and pest in tomato crops in Catalonia, Spain. Entomophaga 33:219-228

Gillespie DR, McGregor R, Sanchez JA, Quiring SL, Van Laerhoven DMJ, Roitberg BD (2007) An endemic omnivorous predator for control of greenhouse pests. In: Vincent C, Goettel M, Lazarovits G et al (eds) Biological control: a global perspective. CABI Publishing, UK, pp 128-135

Godfray HCJ (1994) Parasitoids: behavioural and evolutionary ecology. Princeton University Press, Princeton, New Jersey, USA. 473 pp

Gurr GM, You M (2016) Conservation biological control of pests in the molecular era: new opportunities to address old constraints. Front Plant Sci 6:1255. https://doi.org/10.3389/ fpls.2015.01255

Hagen KS (1962) Biology and ecology of predacious Coccinellidae. Annu Rev Entomol 7:289-326

Hamdan AJS, Abu-Awad IT (2008) Biological aspects of the predatory bug Orius laevigatus (Fiber) [Hemiptera: Anthocoridae] when fed on the tobacco whitefly Bemisia tabaci (Gennadius) [Homoptera: Aleyrodidae] spread on tomato and eggplant. Dirasat: Agric Sci 35:81-91 
Hussey NW, Bravenboer L (1971) Control of pests in glasshouse culture by the introduction of natural enemies. In: Huffaker CB (ed) Biological control. Plenum, New York, USA, pp 195-216

Ingegno BL, Candian V, Psomadelis I, Bodino N, Tavella L (2017) The potential of host plants for biological control of Tuta absoluta by the predator Dicyphus errans. Bull Entomol Res 107(3):340-348

Jacas JA, Urbaneja A, Viñuela E (2006) History and future of introduction of exotic arthropod biological control agents in Spain: a dilemma? BioControl 51:1-30

James DG (2005) Further field evaluation of synthetic herbivore-induced plan volatiles as attractants for beneficial insects. J Chem Ecol 31:481-495. https://doi.org/10.1007/s10886-005-2020-y

Kant MR, Jonckheere W, Knegt B, Lemos F, Liu J, Schimmel BC, Villarroel CA, Ataide LM, Dermauw W, Glas JJ, Egas M, Janssen A, Van Leeuwen T, Schuurink RC, Sabelis MW, Alba JM (2015) Mechanisms and ecological consequences of plant defence induction and suppression in herbivore communities. Ann Bot 115:1015-1051

Lambion J, Ingegno BL, Tavella L, Alomar O, Perdikis D (2016) Companion plants for predatory bugs. Fact sheet no 4. Cost action FA1105 - BioGreenhouse

Lamichhane JR, Bischoff-Schaefer M, Blumel S, Dachbrodt-Saaydeh S, Dreux L, Jansen JP, Kiss J, Köhl J, Kudsk P, Malausa T, Nicot P, Ricci P, Thibierge J, Villeneuve F (2017) Identifying obstacles and ranking common biological control research priorities for Europe to manage most economically important pests in arable, vegetable and perennial crops. Pest Manag Sci 73:14-21

Lanzoni A, Martelli R, Pezzi F (2017) Mechanical release of Phytoseiulus persimilis and Amblyseius swirskii on protected crops. Bull Insectology 70(2):245-250

Lattin JD (1999) Bionomics of the Anthocoridae. Annu Rev Entomol 44:207-231

Lommen STE, de Jong PW, Pannebakker BA (2018) Time to bridge the gap between exploring and exploiting: prospects for utilizing intraspecific genetic variation to optimise arthropods for augmentative pest control. Entomologia Experimentalis et Applicata 162:108-123

Lundgren JG, Fergen JK, Riedell WE (2008) The influence of plant anatomy on oviposition and reproductive success of the omnivorous bug Orius insidiosus. Anim Behav 75:1495-1502

Mallinger RE, Hogg DB, Gratton C (2011) Methyl salicylate attracts natural enemies and reduces populations of soybean aphids (Hemiptera: Aphididae) in soybean agroecosystems. J Econ Entomol 104:115-124

McEwen P, New T, Whittington A (2001) Lacewings in the crop environment. Cambridge University Press, Cambridge, UK. 546 pp

McMurtry JA, Croft BA (1997) Life-styles of Phytoseiid mites and their roles in biological control. Annu Rev Entomol 42:291-321

Messelink GJ, van Steenpaal SEF, Ramakers PMJ (2006) Evaluation of phytoseiid predators for control of western flower thrips on greenhouse cucumber. BioControl 51:753-768

Messelink GJ, van Maanen R, van Steenpaal SEF, Janssen A (2008) Biological control of thrips and whiteflies by a shared predator: two pests are better than one. Biol Control 44:372-379

Messelink GJ, Bennison J, Alomar O, Ingegno BL, Tavella L, Shipp L, Palevsky E, Wäckers FL (2014) Approaches to conserving natural enemy populations in greenhouse crops: current methods and future prospects. BioControl 59:377-393

Messelink GJ, Bloemhard CMJ, Hoogerbrugge H, van Schelt J, Ingegno BL, Tavella L (2015) Evaluation of mirid predatory bugs and release strategy for aphid control in sweet pepper. J Appl Entomol 139:333-341

Moerkens R, Berckmoes E, Van Damme V, Ortega-Parra N, Hanssen I, Wuytack M, Wittemans L, Casteels H, Tirry L, De Clercq P, De Vis R (2016) High population densities of Macrolophus pygmaeus on tomato plants can cause economic fruit damage: interaction with Pepino mosaic virus? Pest Manag Sci 72:1350-1358

Nomikou N, Janssen A, Schraag R, Sabelis MW (2001) Phytoseiid predators as potential biological control agents for Bemisia tabaci. Exp Appl Acar 25:271-291

Nomikou M, Janssen A, Schraag R, Sabelis MW (2002) Phytoseiid predators suppress populations of Bemisia tabaci on cucumber plants with alternative food. Exp Appl Acarol 27:57-68 
Obrycki JJ, Kring TJ (1998) Predaceous Coccinellidae in biological control. Annu Rev Entomol 43(1):295-321

Pappas M, Steppuhn A, Geuss D, Topalidou N, Zografou A, Sabelis MW, Broufas GD (2015) Beyond predation: the zoophytophagous predator Macrolophus pygmaeus induces tomato resistance against spider mites. PLoS One 10(5):e0127251

Pappas ML, Steppuhn A, Broufas GD (2016) The role of phytophagy by predators in shaping plant interactions with their pests. Commun Integr Biol 9(2):e1145320

Park H-H, Shipp L, Buitenhuis R (2010) Predation, development, and oviposition by the predatory mite Amblyseius swirkii (Acari: Phytoseiidae) on tomato russet mite (Acari: Eriophyidae). J Econ Entomol 103(3):563-569

Perdikis D, Fantinou A, Lykouressis D (2011) Enhancing pest control in annual crops by conservation of predatory Heteroptera. Biol Control 59:13-21

Pérez-Hedo M, Urbaneja A (2016) The zoophytophagous predator Nesidiocoris tenuis: a successful but controversial biocontrol agent in tomato crops. In: Horowitz AR, Ishaaya I (eds) Advances in insect control and resistance management. Springer, Dordrecht, pp 121-138

Pérez-Hedo M, Bouagga S, Jaques JA, Flors V, Urbaneja A (2015) Tomato plant responses to feeding behavior of three zoophytophagous predators (Hemiptera: Miridae). Biol Control 86:46-51

Pérez-Hedo M, Rambla JL, Granell A, Urbaneja A (2018) Biological activity and specificity of Miridae-induced plant volatiles. BioControl 63:203-213. https://doi.org/10.1007/ s10526-017-9854-4

Peterson JA, Ode PJ, Oliveira-Hofman C, Harwood JD (2016) Integration of plant defense traits with biological control of arthropod pests: challenges and opportunities. Front Plant Sci 7:1794. https://doi.org/10.3389/fpls.2016.01794

Pineda SM, Figueroa M, José I et al. (2016) Life history, diagnosis, and biological aspects of Engytatus varians (Hemiptera: Miridae), a predator of Bactericera cockerelli (Hemiptera: Triozidae). Biocontrol Sci Tech 26(8):1073-1086

Poinar GO, Grewal PS (2012) History of entomopathogenic nematology. J Nematol 44:153-161

Ravensberg WJ (2011) A roadmap to the successful development and commercialization of microbial pest control products for control of arthropods. Springer, Dordrecht, Netherlands. 383 pp

Research and Markets (2016a) Biopesticides global strategic business report. http://www.researchandmarkets.com/publication/mlv3aqe/347972. Cited 10 March 2017

Research and Markets (2016b) Global pesticides market segmented by type, application area and geography. Trends and forecasts (2015-2020). Sustainability, regulation \& competition. http:// www.researchandmarkets.com/research/4hd338/global_pesticides. Cited 10 March 2017

Sanchez J, Lacasa A (2002) Modelling population dynamics of Orius laevigatus and O. albidipennis (Hemiptera: Anthocoridae) to optimize their use as biological control agents of Frankliniella occidentalis (Thysanoptera: Thripidae). Bull Entomol Res 92:77-88

Secretariat of the Convention on Biological Diversity (2011) Nagoya protocol on access to genetic resources and the fair and equitable sharing of benefits arising from their utilization to the convention on biological diversity: text and annex, Convention on Biological Diversity. United Nations, Montreal, Canada

Silva DB, Bueno VHP, Calvo FJ, van Lenteren JC (2017) Do nymphs and adults of three Neotropical zoophytophagous mirids damage leaves and fruits of tomato? Bull Entomol Res 107(2):200-207

Speyer ER (1927) An important parasite of the greenhouse white-fly (Trialeurodes vaporariorum Westwood). Bull Entomol Res 17:301-308

Symondson WOC, Sunderland KD, Greenstone MH (2002) Can generalist predators be effective biocontrol agents? Annu Rev Entomol 47:561-594

Tommasini MG (2004) Collection of Orius species in Italy. Bull Insectology 57:65-72

Tommasini MG, Nicoli G (1996) Evaluation of Orius spp. as biological control agents of thrips pests. Further experiments on the existence of diapause in Orius laevigatus. OILB/SORP Bull 19:183-186 
Tommasini MG, van Lenteren JC, Burgio G (2004) Biological traits and predation capacity of four Orius species on two prey species. Bull Insectology 57:79-94

van der Blom J (2017) Control Biológico en cultivos hortícolas en Almería: balance después de 10 años. Bol SEEA 2:34-38

van der Ent S, Knapp M, Klapwijk J, Moerman E, van Schelt J, de Weert S, Dik A, Schulthess F (2017) Knowing and recognizing: the biology of pests, diseases and their natural enemies. Koppert Biological Systems, Berken en Rodenrijs. 443 pp.

van Lenteren JC (2000) A greenhouse without pesticides: fact of fantasy? Crop Prot 19:375-384. https://doi.org/10.1016/S0261-2194(00)00038-7

van Lenteren JC (ed) (2003) Quality control and production of biological control agents: theory and testing procedures. CABI Publishing, Wallingford, UK. $327 \mathrm{pp}$

van Lenteren JC (2010) Ecology: cool science, but does it help? Wageningen University, Wageningen. 44 pp. ISBN 978-90-8585-580-4

van Lenteren JC (2012) The state of commercial augmentative biological control: plenty of natural enemies, but a frustrating lack of uptake. BioControl 57:1-20. https://doi.org/10.1007/ s10526-011-9395-1

van Lenteren JC, Woets J (1988) Biological and integrated pest control in greenhouses. Annu Rev Entomol 33:239-269. https://doi.org/10.1146/annurev.en.33.010188.001323

van Lenteren JC, Bale J, Bigler F, Hokkanen HMT, Loomans AJM (2006) Assessing risks of releasing exotic biological control agents of arthropod pests. Annu Rev Entomol 51:609-634. + supplemental material. https://doi.org/10.1146/annurev.ento.51.110104.151129

van Lenteren JC, Hemerik L, Lins JC, Bueno VHP (2016) Functional responses of three neotropical mirid predators to eggs of Tuta absoluta on tomato. Insects 7(3):34. https://doi.org/10.3390/ insects 7030034

van Lenteren JC, Bolckmans K, Köhl J, Ravensberg W, Urbaneja A (2018a) Biological control using invertebrates and microorganisms: plenty of new opportunities. BioControl. https://doi. org/10.1007/s10526-017-9801-4

van Lenteren JC, Bueno VHP, Calvo FJ, Calixto AM, Montes FC (2018b) Comparative effectiveness and injury to tomato plants of three neotropical mirid predators of Tuta absoluta (Lepidoptera: Gelechiidae). J Econ Entomol. 111(3):1080-1086

van Lenteren JC, Bueno VHP, Burgio G, Lanzoni A, Montes FC, Silva DB, de Jong PW, Hemerik L (2019) Pest kill rate as aggregate evaluation criterion to rank biological control agents: a case study with Neotropical predators of on tomato. Bull Entomol Res 1-9. https://doi.org/10.1017/ S0007485319000130

van Maanen R, Vila E, Sabelis MW, Janssen A (2010) Biological control of broad mites (Polyphagotarsonemus latus) with the generalist predator Amblyseius swirskii. Exp Appl Acarol 52(1):29-34

Venzon M, Janssen A, Sabelis MW (2002) Prey preference and reproductive success of the generalist predator Orius laevigatus. Oikos 97:116-124

Vet LEM, Dicke M (1992) Ecology of infochemical use by natural enemies in a tritrophic context. Annu Rev Entomol 37:141-172

Wäckers FL, van Rijn PCJ, Bruin J (eds) (2005) Plant-provided food for carnivorous insects: a protective mutualism and its applications. Cambridge University Press, Cambridge, UK. 356 pp

Wheeler AG (2001) Biology of the plant bugs (Hemiptera: Miridae): pests, predators, opportunists. Cornell University Press, Cornell, USA. 507 pp

Wheeler AG, Krimmel BA (2015) Mirid (Hemiptera: Heteroptera) specialists of sticky plants: adaptations, interactions, and ecological implications. Annu Rev Entomol 60:393-414 